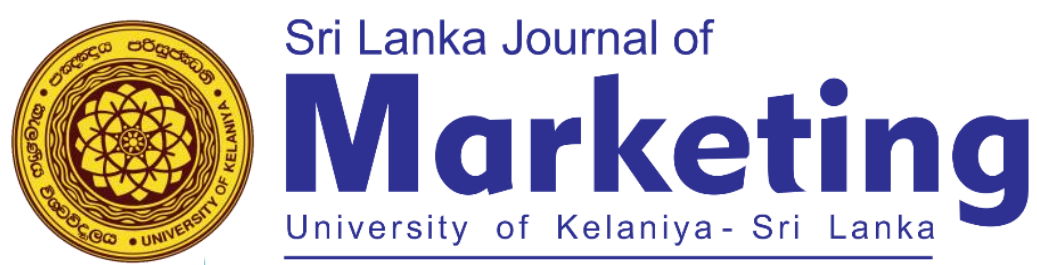

\title{
Adolescent Consumer Vulnerability: Consumer Socialization Perspective
}

\section{A Systematic Literature Review}

\author{
Nishadi G.P.K. \\ PhD Candidate, University of Sri Jayewardenepura, Sri Lanka \\ nishadi@mgt.ruh.ac.lk \\ Warnakulasooriya B.N.F \\ Professor, University of Sri Jayewardenepura, Sri Lanka \\ neville@sjp.ac.lk \\ Chandralal K.P.L. \\ Senior Lecturer, University of Sri Jayewardenepura, Sri Lanka \\ kpl@sjp.ac.lk
}

DOI: http://doi.org/10.4038/sljmuok.v7i3.75

\begin{abstract}
Understanding variety of areas of vulnerabilities that Adolescent Consumers are facing in today's market place is very important and broadly discussed topic within the current literature. However, desired research findings do not exist to figure out what exactly Adolescent Consumer vulnerability refers and actual vulnerabilities, adolescents are facing via socialization. Within this backdrop, this systematic literature review conducted to fill those existing knowledge gaps and identify suitable research areas and future prospects within the field of Adolescent Consumer Vulnerability from Socialization perspective. A careful examination of 40 papers, published within 2005-2020 period led to the identification of five research areas with current importance. Thus, the study revealed how; Peers, Parents, TV Advertising, Online context and Retailers, influence on Adolescent Consumer Vulnerability. Finally, the review results highlighted the existing knowledge gap of moderating role played by socio demographic structure on the direct relationship between Socialization Agents and Adolescent Consumer Vulnerability.
\end{abstract}

Keywords: Adolescent Consumer Vulnerability, Research Gaps, Socialization Agents, Socio-Demographic Structure, Systematic Literature Review

ORCID of authors: Nishadi G.P.K. - (ID) https://orcid.org/0000-0001-7800-5926 Chandralal K.P.L.- (D) https://orcid.org/0000-0003-4974-7925

Copyright: This is an open access article distributed under the Creative Commons Attribution License 4.0, which permits unrestricted use, distribution, and reproduction in any medium, provided the original work is properly cited. 


\section{INTRODUCTION}

Consumers, who are vulnerable, fail to understand their own preferences and lack the knowledge, skills, or freedom to act on them. (Baker et al., 2005; Ringold, 2005; Taylor et al, 2005). Although, growing number of studies are available pertaining to consumer vulnerability, the field lacks clarity on who experiences vulnerability and what is the consumer perception of his vulnerability (Paul \& Sharma, 2020; Batat, 2012).

Understanding Consumer Vulnerability from a Class or Group-focused perspective is useful and certain classes should be identified as more likely to experience vulnerability (Kennedy, et al, 2019; Commuri \& Ekici, 2008;). Further, Commuri and Ekici (2008), proposed that the traditional underprivileged consumer conceptualization based on demographic or categories may undeniably be useful and should not be abandoned. Thus, extant literature revealed that consumers are vulnerable due to; Low literacy and language skills (Stewart \& Yap , 2020; Jayasundara et al, 2020; Nishadi, 2020; Crowell, 2014; Broderick et al, 2011), Gender (Lacoba et al, 2020; Li et al, 2020; Fox \& Hoy, 2019; McCoy et al, 2017; Nora et al, 2015; Svensson 2003; Barber, 2013) Lack of resources (FCA, 2014; Canhotoa \& Dibb, 2016), Income (Powell \& Binh, 2013; Li et al, 2020; Khan et al, 2012; Bowman et al, 2004), Social Class (Paniagua et al ,2014; Ranjith et al, 2015; Skårdal et al, 2014; Svastisalee, et al, 2012; Wills et al, 2009; Hanson and Chen, 2007) and Older age (Melnikas \& Smaliukiene, 2007; Moschis et al, 2011; Silvera, Meyer \& Laufer; Berg, 2015).

Although, a significant number of researches are available on consumer vulnerability, desired research findings are not enough to figure out the vulnerability of Adolescents to various Socialization Agents (Kennedy, et al, 2019; Somasiri and Chandralal, 2018; Luo, 2005).

Further, the existing consumer vulnerability researches suggested that future researches should concentrate more on young consumers, by moving the focus away from adult perspective to adolescent perspective shaped by the norms of the youths' consumption subcultures (Batat \& Tanner, 2019; Mason et al., 2013; Batat, 2012; Pechmann et al., 2011).

While explaining the importance of Peers, Parents and TV advertising as traditional agents of socialization (Ubayachandra \& Eldeniya, 2017; Jain \& Sharma, 2016; Lenka \& Vandana, 2015; Barber, 2013; Abbas et al, 2013), the extant literature highlighted the importance of studying the influence of Internet (Batat and Jfner, 2019; Barber, 2013), Social Media (Niankara et al, 2020; Kennedy et al, 2019; Somasiri and Chandralal, 2018), and Retailers (Thyne et al, 2019; Grier and Davis, 2013) on adolescent consumer vulnerability.

With the understanding of these existing knowledge gaps, we conducted this systematic literature review to elaborate the concept of Adolescent consumer vulnerability in Socialization perspective (RQ1), followed by the recognition of current research gaps and future research avenues (RQ3). 
Additionally, we presented an evolution of key theoretical discussions made during 2005-2020 period relevant to the field (RQ2).

\section{METHODOLOGY}

Literature reviews direct researchers to map and assess the existing intellectual territory, and to specify a research question to develop the existing body of knowledge further. (Tranfield, Denyer and Smart, 2003).

According to Kitchenham and Charters (2007), A Systematic Literature Review (SLR) can be conducted under three phases namely; Defining a Review Protocol, Conducting the Review and Reporting the findings. Based on the above understanding, this review conducted under three steps as follows.

\subsection{Defining a Review Protocol}

The outcome of a systematic review captures through a formal document called a review protocol. The protocol is a plan that helps to protect objectivity by providing explicit descriptions of the steps that researchers should undertake. The protocol contains information on the specific questions addressed by the study, the population (or sample) that is the focus of the study, the search strategy for identification of relevant studies, and the criteria for inclusion and exclusion of studies in the review (Davies and Crombie, 1998). Thus, the Review Protocol of this specific study presents as follows.

\subsection{Research Questions and Objectives}

The aim of this systematic literature review is to understand the different areas and future prospects of Adolescent Consumer Vulnerability from Socialization Perspective. As such, we developed three research questions followed by three objectives as follows.

Table 1: Research Questions and Objectives of the Study

\begin{tabular}{|l|l|}
\hline \multicolumn{1}{|c|}{ Research Questions } & \multicolumn{1}{c|}{ Research Objectives } \\
\hline $\begin{array}{l}\text { RQ1 - How the concept of Adolescent Consumer } \\
\text { Vulnerability through Socialization Agents, explored } \\
\text { within the existing body of literature? }\end{array}$ & $\begin{array}{l}\text { To elaborate the concept of Adolescent consumer } \\
\text { vulnerability in Socialization perspective. }\end{array}$ \\
\hline $\begin{array}{l}\text { RQ2- What key theoretical discussions made in the } \\
\text { area of consumer vulnerability? }\end{array}$ & $\begin{array}{l}\text { To evolve and explore the new concepts and theories } \\
\text { built relevant to the field of Adolescent Consumer } \\
\text { Vulnerability. }\end{array}$ \\
\hline $\begin{array}{l}\text { RQ3 - What are the existing research gaps and } \\
\text { possible avenues for future researches? }\end{array}$ & $\begin{array}{l}\text { To elaborate empirical findings relating to the gaps } \\
\text { identified. }\end{array}$ \\
\hline
\end{tabular}




\subsection{Search Strategy}

For facilitating the literature search, we used several key terms when searching the articles such as; consumer vulnerability, impact of socialization agents on adolescent consumer vulnerability, peer pressure on adolescent consumer vulnerability, impact of parents on adolescent consumer vulnerability, adolescent consumer vulnerability in online transactions, advertising exposure and adolescent consumer vulnerability, social media and adolescent consumer vulnerability and retailers influence on adolescent consumer vulnerability.

Based on the above key words search, articles published within the last 15 years period (from 20052020) in English found from publishers such as Emerald, ELSVEIR, Taylor and Francis, Wiley, Sage and Western Publishers. Additionally, we used snowballing technique to have more papers, by scanning the reference list and bibliographies of the selected articles. Moreover, by personally writing to the relevant authors, we got papers that were not possible to access.

\subsection{Inclusion and Exclusion Criteria}

Through extensive search of existing literature, we considered articles to meet inclusion criteria; the Title of the research, the Year of publication (within the last 15 years' period), Area of focused, Methodology used, Type of the Journal and the Context.

Additionally, our selection process was based on the recognition of the journal and number of citations. Thus, we selected and synthesized articles published; in peer reviewed journals, on or after 2005, relevant to the area of Adolescent Consumer Vulnerability, with a rigorous methodology.

\subsection{Data Synthesis}

During this stage, we synthesised the available data by giving special reference to the year of publication, publication venue, contribution to the existing body of knowledge, methodology used, key research findings and research gaps identified.

\subsection{Conduct the Review}

The review process took place under three basic steps aligning with the elements included in the Review Protocol. 


\subsection{Identification of Primary Studies}

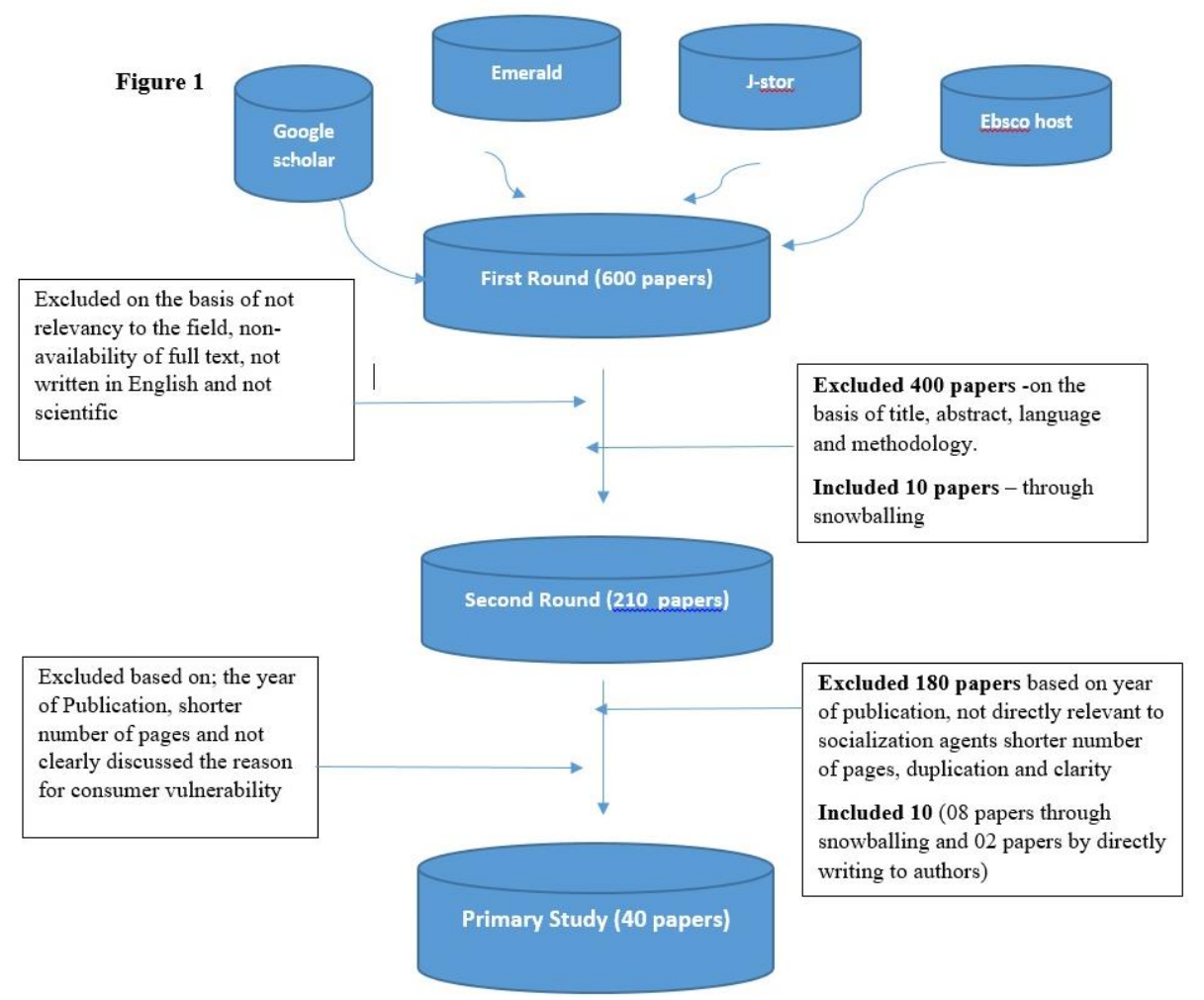

As depicted in the Figure 01, the study population refers the narrow area of Adolescent Consumer Vulnerability coming under the broader area of Consumer Vulnerability and search string took place accordingly. Thus, we used several key terms; Socialization Agents on adolescent consumer vulnerability, Peer pressure on adolescent consumer vulnerability, Parents on adolescent consumer vulnerability, Adolescent consumer vulnerability in Online transactions, Advertising exposure and adolescent consumer vulnerability, social media and Adolescent consumer vulnerability and Retailers' influence on adolescent consumer vulnerability.

When it comes to review process, we had 600 papers during the initial round and filtered them based on several criteria. At this stage, our selection process did not consider papers that are; not directly relevant to the field of Adolescent Consumer Vulnerability, available without full-text, not written in English and not scientific. As a result, we got 210 papers that are directly relevant to the field.

During the second round, another set of papers were rejected (180 were removed and 10 were included) from the analysis, grounding that those; were published before 2005, have shorter number of pages (less than 3), are not clearly focused the reason for consumer vulnerability and are duplicate papers. At the end, we chose 40 primary studies for the synthesis. 


\subsection{Data Analysis}

The upcoming two sections outline the detailed review process aligning with research questions and objectives. The section no: 03 presents the current uses of Adolescent Consumer Vulnerability under five different themes; Current use of Adolescent Consumer Vulnerability, Publication venue, Areas of Adolescent Consumer Vulnerability, Research methods deployed and Evolution of key theoretical discussions. The section 04 discusses existing research gaps and suggestions for future researches, whereas section 05 outlines discussion and conclusion.

\section{CURRENT USES OF ADOLESCENT CONSUMER VULNERABILITY}

This section encompasses current uses of Adolescent Consumer Vulnerability based on the Year of publication, Publication venue, Areas of focus, Methodology used and Key theoretical discussion.

\subsection{Analysis of Current Use of Adolescent Consumer Vulnerability}

In line with RQ1, we started our analysis to identify the annual number of researches, conducted within the field from 2005-2020 period. This type of categorization is beneficial, because it clearly indicates the recent movement of researches available in current body of knowledge.

According to the data on table 02, it is obvious that most of the researches are available in year 2019 whereas less studies in years 2014, 2016 and 2018. However, no study is existed out of 40, both in years 2007 and 2011.

Table 2: Current use of Consumer Vulnerability

\begin{tabular}{|l|l|c|}
\hline Year & \multicolumn{1}{|c|}{ Paper ID } & No: of Researches \\
\hline 2005 & P10, P30, P33, & 03 papers \\
\hline 2006 & P18, P25, & 02 papers \\
\hline 2007 & ----- & 04 papers \\
\hline 2008 & P02, P09, P34, P35 & 03 papers \\
\hline 2009 & P28, P29, P40 & 03 papers \\
\hline 2010 & P03, P08, P32 & ----- \\
\hline 2011 & ----- & 03 papers \\
\hline 2012 & P04, P21, P39 & 04 papers \\
\hline 2013 & P01, P15, P17, P26, & 01 paper \\
\hline 2014 & P06 & 02 papers \\
\hline 2015 & P12, P24, & 01 papers \\
\hline 2016 & P16 & 04 papers \\
\hline 2017 & P11, P19, P23, P27, & 01 papers \\
\hline 2018 & P07 & \\
\hline
\end{tabular}




\begin{tabular}{|l|l|c|}
\hline 2019 & P05, P13, P20, P19, P19, P38 & 06 papers \\
\hline 2020 & P14, P16, P31, & 03 papers \\
\hline
\end{tabular}

\subsection{Analysis of Papers based on the Publication Venue}

The aim of this categorization is to identify the variety of venues that the publications are existed. As shown in table 03 , majority of papers out of 40 , are available in Peer reviewed journals, while only one in each of the other three categories; Published books, international conferences and Project reports.

Table 3: Analysis of Publication Venue

\begin{tabular}{|l|l|c|}
\hline \multicolumn{1}{|c|}{ Publication Venue } & \multicolumn{1}{|c|}{ Paper ID } & \multicolumn{1}{|c|}{$\begin{array}{c}\text { No: of } \\
\text { Publications }\end{array}$} \\
\hline \multirow{3}{*}{ Journals } & P1, P02, P03, P04, P05, P06, P07, P08, P09, P10, P11, P13, & \\
& $\begin{array}{l}\text { P14, P15, P17, P19, P20, P21, P22, P23, P24, P25, P26, P27, } \\
\text { P28, P29, P30, P31, P32, P33, P34, P35, P36, P37, P38, P39, } \\
\text { P40 }\end{array}$ & 37 \\
\hline Published Books & P16 & 01 \\
\hline $\begin{array}{l}\text { International } \\
\text { Conferences }\end{array}$ & P18 & 01 \\
\hline Project Reports & P12 & 01 \\
\hline
\end{tabular}

\subsection{Evolution of Key Theoretical Discussions}

Bring into line with RQ2, one of the objectives of this review is to evolve and explore the key theoretical discussions made by the previous authors to the current body of knowledge. By doing so, this paper will understand the untouched areas of existing knowledge and provide suggestions for future avenues. According to the table 04, the discussion starts from Pechman et al (2005) two important characteristics of Adolescent Consumer Vulnerability namely; Impulsiveness and Self-consciousness. During the same year, Dotson and Hyatt introduced five major consumer socialization influence factors: Irrational social influence, Importance of television, Familial influence, Shopping importance, and Brand importance. Later, in 2008 Batat discovered six themes of Adolescents' learning through the interaction on the Internet; Learning through 'trial and error', Multi-tasking, Observational and mutual learning, learning through self-experience, Learning through virtual communities and Learning through multiple sources. Next, the six key features of interactive media introduced by Montogramy and Chestor (2009) are ubiquitous connectivity, personalization, peer-to-peer networking, engagement, immersion, and content creation.

Later, Batat (2010) identified two categories of young consumer vulnerability in online transactions namely; Info-pollution and Enslavement. Subsequently, Batat (2012) introduced another six categories of Adolescent consumer vulnerability; Impulsivity and self-conscious, Incapacity of making 
independent and confident decisions, Incapacity to resist peer group pressure, Lack of knowledge and consumption experiences, The paradox of the digital society, and Use of risky online communities as a confident source of information. Afterward, Hill et al, (2013) uncovered five basic motivations and two shopping motivations influencing adolescent online usage and shopping namely; Online shopping enjoyment motivations, Online shopping value motivations, online social motivations, Online playfulness motivations, Online discovery motivations, Online escapism motivations, Online usefulness motivations. Further, the findings of Barber (2013) suggested that normative influence of parents, peers, and the Internet affect Generation Y more than Generation X. In contrast, the same study found that informative influences of parents, traditional media, and in particular, the Internet affect Generation X. Subsequently, a new approach to the consumer vulnerability field, that is, childhood as a hybridised, fluid combination of structure and agency, introduced by Spotwood and Nairn in 2016. Next, Berg (2018) introduced a model to identify the drivers influence on consumption patterns in digital context. Finally, Batat and Tanner (2019) presented an important framework to the existing literature that is Adolescent-centric vulnerability (ACV) framework to explain the meanings, drivers, and outcomes of consumer vulnerability from an adolescent perspective.

Table 4: Key Theoretical Discussions

\begin{tabular}{|c|c|c|c|c|}
\hline Author/s & Year & Findings & $\begin{array}{l}\text { Paper } \\
\text { ID }\end{array}$ & Contexts \\
\hline $\begin{array}{l}\text { Pechmann et } \\
\text { al }\end{array}$ & 2005 & $\begin{array}{l}\text { Authors introduced Impulsiveness and Self-consciousness as } \\
\text { two important characteristics of Adolescent Vulnerability. }\end{array}$ & P33 & $\begin{array}{l}\text { Multiple } \\
\text { contexts }\end{array}$ \\
\hline $\begin{array}{l}\text { Dotson and } \\
\text { Hyatt }\end{array}$ & 2005 & $\begin{array}{l}\text { Five major consumer socialization influence factors emerged: } \\
\text { Irrational social influence, Importance of television, Familial } \\
\text { influence, Shopping importance, and Brand importance; }\end{array}$ & P10 & U.S.A. \\
\hline Batat W. & 2008 & $\begin{array}{l}\text { Batat explained Adolescents' learning through the interaction } \\
\text { on the Internet under six themes. } \\
\text { 1. Learning through 'trial and error' } 2 \text {. Multi-tasking } 3 \text {. } \\
\text { Observational and mutual learning } 4 \text {. Learning through self- } \\
\text { experience 5. Learning through virtual communities } 6 \text {. } \\
\text { Learning through multiple sources }\end{array}$ & P02 & French \\
\hline $\begin{array}{l}\text { Montgomery } \\
\text { and Chester }\end{array}$ & 2009 & $\begin{array}{l}\text { Six key features of interactive media-ubiquitous } \\
\text { connectivity, personalization, peer-to-peer networking, } \\
\text { engagement, immersion, and content creation-are } \\
\text { emblematic of the ways in which young people are both } \\
\text { shaping and being shaped by this new digital culture }\end{array}$ & P29 & $\begin{array}{l}\text { Multiple } \\
\text { contexts }\end{array}$ \\
\hline Batat W. & 2010 & $\begin{array}{l}\text { Author Identified two categories of young consumer } \\
\text { vulnerability in online transactions namely; } \\
\text { 1.Info-pollution } \\
\text { 2. Enslavement. } \\
\text { The first category called info-pollution defined as a } \\
\text { misinformation and as an info-abundance. The second } \\
\text { category is the enslavement of this digital generation who is } \\
\text { growing up in a very high technological context and who } \\
\text { always connect to the virtual world through the Internet. }\end{array}$ & P03 & French \\
\hline
\end{tabular}




\begin{tabular}{|c|c|c|c|c|}
\hline Batat W. & 2012 & $\begin{array}{l}\text { The results revealed six categories related to young } \\
\text { consumer's perception of vulnerability within their youth } \\
\text { subculture: } \\
\text { 1) impulsivity and self-conscious, 2) incapacity of making } \\
\text { independent and confident decisions, 3) incapacity to resist } \\
\text { peer group pressure, 4) lack of knowledge and consumption } \\
\text { experiences, 5) the paradox of the digital society, and 6) using } \\
\text { risky online communities as a confident source of information. } \\
\text { Further, authors defined Adolescents Consumer Vulnerability } \\
\text { in two folds as follows. } \\
\text { 1. Deliberate Vulnerability (ex: surfing porn websites is a } \\
\text { desired behaviour by showing their independence and their } \\
\text { resistance to adults' rules) } \\
2 . \text { Imposed Vulnerability (ex: purchasing brands that they } \\
\text { can’t afford). }\end{array}$ & P04 & French \\
\hline Hill et al & 2013 & $\begin{array}{l}\text { Five basic motivations and two shopping motivations } \\
\text { influencing adolescent online usage and shopping were } \\
\text { identified namely; Online shopping enjoyment motivations, } \\
\text { Online shopping value motivations, online social motivations, } \\
\text { Online playfulness motivations, Online discovery motivations, } \\
\text { Online escapism motivations, Online usefulness motivations }\end{array}$ & P17 & U.S.A. \\
\hline Barber & 2013 & $\begin{array}{l}\text { The findings suggest that normative (parents, peers, and the } \\
\text { Internet) influences affect Generation Y more than Generation } \\
\text { X. Conversely, as this study found, informative influences of } \\
\text { parents, traditional media, and in particular, the Internet affect } \\
\text { Generation X. }\end{array}$ & P01 & U.S.A \\
\hline $\begin{array}{l}\text { Spotwood } \\
\text { and Nairn }\end{array}$ & 2016 & $\begin{array}{l}\text { This paper introduces a new approach to the consumer } \\
\text { vulnerability field, that is, childhood as a hybridised, fluid } \\
\text { combination of structure and agency. }\end{array}$ & P37 & $\begin{array}{l}\text { Multiple } \\
\text { Contexts }\end{array}$ \\
\hline Berg. L. & 2018 & $\begin{array}{l}\text { Researcher introduced a model to identify the drivers influence } \\
\text { on consumption patterns in digital context. }\end{array}$ & P07 & Norwegian \\
\hline $\begin{array}{l}\text { Batat and Jr. } \\
\text { Tanner }\end{array}$ & 2019 & $\begin{array}{l}\text { Authors developed Adolescent-centric vulnerability (ACV) } \\
\text { framework to explain the meanings, drivers, and outcomes of } \\
\text { consumer vulnerability from an adolescent perspective. }\end{array}$ & P05 & French \\
\hline
\end{tabular}

\subsection{Analysis of Areas of Adolescent Consumer Vulnerability}

This part of analysis tries to address RQ1 while identifying the key areas of adolescent consumer vulnerability in socialization perspective. As depicted in Table 05, primary studies categorized into five different areas namely; Peer pressure on adolescent consumer vulnerability, Parents influence on adolescent consumer vulnerability, Adolescent consumer vulnerability in online context, Advertising exposure and adolescent consumer vulnerability, and Retailers influence on adolescent consumer vulnerability.

The highest number of publications discusses the adolescent consumer vulnerability in online context, due to its prevailing importance within the present world. Thus, extant literature highlighted the impact of; new media on Y generation (Barber, 2013), internet on consumption skills (Batat, 2008), internet 
exposure on adolescent vulnerability (Kennedy et al, 2019; Batat, 2010), digital practices, for instance posting selfies and following bloggers on over consumption (Berg, 2018), online triggers on adolescent online usage and shopping (Hill et al, 2013), mobile technology and gambling on millennial consumer (Josephin et al, 2006), internet addition on adolescents' mental health (Karacic and Oreskovic, 2017), gaming addiction on adolescents (Kuss and Griffiths, 2012), frequency of ecological website visits, news blogs visits, and web-browsing on youths' interests in ecosystem services and sustainability (Niankara et al, 2010) and ultimately, online context on adolescents privacy concerns (Youn, 2009).

The second highest number of publications elaborated Adolescent consumer vulnerability owing to TV advertising. As such, the extant studies discover how; Junk food marketing and media campaigns influence on adolescents' healthy eating (Harris et al, 2020, Elliot, 2017; Beaudon, 2014), children and adolescents are vulnerable due to TV advertising (Lapierre and Rozendaal, 2019), TV advertising influence on adolescents' dietary behaviour and family conflict (Lapierre et al, 2017) and adolescents' attitudes and values are influenced by advertising (Nairn and Berthon (2005).

The studies which consider Peer Pressure on Adolescent Consumer Vulnerability strives to reveal; how Adolescents' engagement in various behaviours are determined by peer relations (Crosnoe and McNeely (2008), how Peers have a direct influence on adolescents' risky behaviour (Tome and Matos 2012), how higher susceptibility to peer pressure will influence higher adolescent consumer vulnerability (Miller, 2009) and how adolescents' fast food consumption is determined by peer influence (Fortin and Yazbeck 2015).

Next, Parents influence on adolescent highlighted that; parents are the most effective source in encouraging adolescents to eat healthy food (Chan et al, 2010), Children are vulnerable through the posts in social media by their parents (Fox and Hoy, 2019), parents are more influential than peer group in fast food consumption (Gilmour et al, 2020; Rydell et al, 2008).

When it comes to Retailers' influence on adolescent vulnerability, findings revealed that adolescents are vulnerable due to; proximity to retail shop (Grier and Davis, 2013), higher involvement with a channel and agent (Lueg et al, 2006), and promotional strategies of retailers (Thyne et al (2019).

Finally, several studies highlighted the combined effect of more than one socialization agent on adolescent consumer vulnerability. Accordingly, Dotson and Hyatt (2005) identified five factors of consumer socialization: familial influence, importance of television, irrational social influence, shopping importance, and brand importance. Findings of Lenka and Vandana, (2015), compares four socialization agents and revealed that family and peer pressure are more important than tv advertising and retailers. Roberts et al (2008) also compare the impact of two socialization agents and uncover that peer normative influence has a relatively stronger influence than parental informative influence. Further, Ozdogan and Atlantis (2010), discovers that children's perceptions of advertisements can be altered through Parent-child co-viewing of advertisements. 
Table 5: Areas of Consumer Vulnerability

\begin{tabular}{|l|l|}
\hline \multicolumn{1}{|c|}{ Area of Vulnerability } & \multicolumn{1}{c|}{ Paper ID } \\
\hline Peer Pressure on Adolescent Consumer Vulnerability & P05, P09, P12, P27, P28, P39 \\
\hline Parents' Influence on Adolescent Consumer Vulnerability & P08, P13, P14, P35 \\
\hline TV Advertising on Adolescent Consumer Vulnerability & P06, P11, P16, P22, P23, P30, P33 \\
\hline Adolescent Consumer Vulnerability in Online contexts & $\begin{array}{l}\text { P01, P02, P03, P04, P07, P17, P18, P19, } \\
\text { P20, P21, P29, P31, P40 }\end{array}$ \\
\hline Retailers' influence on Adolescent Consumer Vulnerability & P15, P25, P38 \\
\hline More than one Socialization agent & P10, P24, P26, P32, P34, P36, P37 \\
\hline
\end{tabular}

\subsection{Research Methodology Deployed}

The aim of this part of analysis is to categorize the primary studies based on the research methods deployed. The data on table 06 visually depicts the alternative research methods used by the extant researchers within their studies.

Accordingly, review papers put into four categories namely, Qualitative, Quantitative, Mixed methods and Literature Reviews. As per the table 06, exactly 50\% (20 papers) of studies out of 40, are Quantitative researches coming under two basic data collection methods; Survey based questionnaire and Experimental Design. Even among the quantitative data collection methods, survey-based questionnaire is the technique used by majority of researchers (P01, P06, P07, P08, P10, P12, P15, P19, P22, P24, P25, P28, P31, P32, P34, P36, P39, P40) while experimental design in very few papers (P30, $\mathrm{P} 35)$.

The second highest number of papers (11 papers) come under literature reviews of five categories; Theoretical Literature Review, Systematic Literature Review, Narrative Literature Review, Integrative Literature Review and Argumentative Literature Review. Even among the 11 literature reviews, Integrative literature review applied in 04 studies (P16, P29, P33, P09) while Theoretical literature reviews in 03 studies (P18, P20, P26). The next set of papers include 02 Systematic literature reviews (P21, P27) and 02 Argumentative literature reviews (P23, P37). However, not a single study found relating to Narrative Literature Review.

Although, Qualitative Research design is one of the dominant research methodologies in behavioural sciences, it used only in 06 primary studies, out of the 40 . Among them, relatively higher use of focus groups (P11, P14, P38) underpins that Adolescents behaviour better measures, via a specific respondent group. Apart from focus groups, Ethnography (P02, P05) and In-depth Interviews (P13) deployed in the rest of 03 primary studies.

Ultimately, Mixed methods applied in three primary studies, with Observation plus Interview in 02 studies (P03, P04) while Interview plus Survey in the rest (P17). 


\begin{tabular}{|c|c|c|c|}
\hline Method & Data Collection Technique & Primary study & No: of papers \\
\hline Quantitative & $\begin{array}{l}\text { 1. Survey based questionnaire } \\
\text { 2. Experimental Design }\end{array}$ & $\begin{array}{l}\text { P01, P06, P07, P08, P10, } \\
\text { P12, P15, P19, P22, P24, } \\
\text { P25, P28, P31, P32, P34, } \\
\text { P36, P39, P40 } \\
\text { P30, P35 }\end{array}$ & $\begin{array}{l}02 \\
\text { (Total 20) }\end{array}$ \\
\hline Qualitative & $\begin{array}{l}\text { 1.In-depth Interviews } \\
\text { 2. Ethnography } \\
\text { 3. Focus group }\end{array}$ & $\begin{array}{l}\text { P13 } \\
\text { P02, P05 } \\
\text { P11, P14, P38 }\end{array}$ & $\begin{array}{l}01 \\
02 \\
03 \\
\text { (Total 06) } \\
\end{array}$ \\
\hline Mix methods & $\begin{array}{l}\text { 1. Observation and Interview } \\
\text { 2. Interview and Survey }\end{array}$ & $\begin{array}{l}\text { P03, P04 } \\
\text { P17 }\end{array}$ & $\begin{array}{l}02 \\
01 \\
\text { (Total 03) }\end{array}$ \\
\hline $\begin{array}{l}\text { Literature } \\
\text { Reviews }\end{array}$ & $\begin{array}{l}\text { 1.Theoritical Literature Review } \\
\text { 2. Systematic Literature Review } \\
\text { 3. Narrative Literature Review } \\
\text { 4. Integrative Literature Review } \\
\text { 5. Argumentative Literature } \\
\text { Review }\end{array}$ & $\begin{array}{l}\text { P18, P20, P26, } \\
\text { P21, P27 } \\
----- \\
\text { P16, P29, P33, P09, } \\
\text { P23, P37 }\end{array}$ & $\begin{array}{l}03 \\
02 \\
04 \\
02 \\
\text { (Total 11) }\end{array}$ \\
\hline
\end{tabular}

\section{EXISTING RESEARCH GAPS AND SUGGESTIONS FOR FUTURE RESEARCHES}

As per the extant literature, majority of studies of adolescent consumer vulnerability have focused on; how Peer pressure influence on adolescent consumer vulnerability, how Internet exposure leads to adolescent vulnerability, how exposure to TV advertising creates adolescent consumer vulnerability, how family, especially parents' put children into vulnerability and how strategies of retailers make people vulnerable.

For instance, findings of Peer Pressure (as shown in table 07), reveals that; there is a positive relationship between peer effects and adolescent eating behaviour (Fortin and Yazbeck 2015), higher susceptibility to peer pressure will influence higher misbehaviour among adolescents (McCoy et al, 2017; Miller, 2009), peer pressure directly influences Adolescents risky behaviour (Tome and Matos, 2012).

Further, extant knowledge highlights that, Adolescents are vulnerable due to; Internet addiction (Kenneday et al, 2019; Karacic and Oreskovic, 2017), E-marketers' information collection practices (Karacic \& Kriz 2017; Lapierre et al., 2017; Elizabeth et al., 2014; Crosnoe \& McNeely, 2008), Higher exposure to social media such as posting selfies and following blogger (Fox and Hoy, 2019; Berg, 2018; Somasiri and Chandralal, 2018) and Gaming addiction (Kuss and Griffiths, 2012, Josephine et al 2006).

Additionally, it is evident that junk food marketing appeals (Harris et al, 2020; Elliot, 2017; Lapierre et al, 2017; Beaudon, 2014) over exposure to TV advertising (Galdolage \& Wijesundara, 2007; Lenka \& 
Vandana, 2015, Pechmann etal., 2005; Lapierre etal., 2017; Rowthorn 2017), deceptive product claims in ads (McInnis \& de Mello, 2005; Watson et al, 2011) put adolescents into vulnerable situation, making them powerless in decision making.

However, desired research findings do not exist to figure out the role of socio-demographic variables, and how those variables may alter the relationship between socialization agents and adolescent consumer vulnerability (Shin et al, 2019; Lenka and Vandana, 2015; Hill et a, 2013; Grier and Davis, 2013, Lueg et al, 2006). Meanwhile, the existing authors highlighted the importance of studying several socio-economic variables; Age cohorts (Lapierre et al, 2017; Lenka and Vandana,2015; Ozdogan and Atlantis,2010; Chan et al, 2010) Gender (McCoy et al 2017; Ozdogan and Atlantis, 2010), Family status (Gilmour et al, 2020; Fox and Hoy, 2019; Shin et al, 2019; Lenka and Vandana, 2015; Lueg et al, 2006) in upcoming researches.

Furthermore, majority of studies are cross sectional, which is not possible to elaborate how adolescents' understanding of socialization influence changes across ages and media platforms (Lapierre et al, 2017). Further, extant literature suggested that longitudinal studies elaborating the impact of age cohorts and media platforms should be studied in more detailed within future endeavours (Lapierre and Rozendaal, 2019; Lapierre et al, 2017).

Within this backdrop, it is obvious that future researchers should pay attention to the moderating role played by socio demographic structure on the relationship between socialization agents and adolescent consumer vulnerability. Additionally, Longitudinal Research, exploring the impact of different time zones on changing adolescent behaviour should also be studied in future researches.

Table 7: Research gaps and avenues for future researches

\begin{tabular}{|c|c|c|c|c|}
\hline $\begin{array}{c}\text { Issues } \\
\text { concerned }\end{array}$ & $\begin{array}{c}\text { Existing } \\
\text { methodology } \\
\text { used }\end{array}$ & What is existed & What is not existed & $\begin{array}{l}\text { Suggestions for } \\
\text { future researches }\end{array}$ \\
\hline $\begin{array}{l}\text { 1. Peer } \\
\text { pressure on } \\
\text { Adolescent } \\
\text { Consumer } \\
\text { Vulnerability. } \\
\text { 2. Impact of } \\
\text { Parents on } \\
\text { Adolescent } \\
\text { Consumer } \\
\text { Vulnerability. }\end{array}$ & $\begin{array}{l}\text { Cross } \\
\text { sectional } \\
\text { studies using, } \\
\text { Qualitative, } \\
\text { Quantitative } \\
\text { and Mixed } \\
\text { methods. }\end{array}$ & $\begin{array}{l}\text { Adolescent Consumer } \\
\text { Vulnerability in Socialization } \\
\text { Perspective } \\
\text { Peer Pressure } \\
\text { Higher susceptibility to peer } \\
\text { pressure will influence higher } \\
\text { misbehaviour among } \\
\text { adolescents (McCoy et al, 2017; } \\
\text { Miller, 2009), } \\
\text { Peer pressure directly } \\
\text { influences Adolescents risky } \\
\text { behaviour (Tome and Matos, } \\
\text { 2012). } \\
\text { Online Context }\end{array}$ & $\begin{array}{l}\text { Knowledge Gaps } \\
\text { 1. The field lacks studies to } \\
\text { elaborate the role of socio- } \\
\text { demographic variables, and } \\
\text { how those variables may } \\
\text { alter the relationship } \\
\text { between socialization agents } \\
\text { and adolescent consumer } \\
\text { vulnerability (Shin et al, } \\
\text { 2019; Lenka and Vandana, } \\
\text { 2015; Hill et a, 2013; Grier } \\
\text { and Davis, 2013, Lueg et al, } \\
\text { 2006). } \\
\text { 2. Further, extant Literature } \\
\text { highlighted the importance } \\
\text { of studying socio- }\end{array}$ & $\begin{array}{l}\text { Based on what is } \\
\text { existed and not } \\
\text { existed, it is } \\
\text { obvious that future } \\
\text { researchers should } \\
\text { pay attention to the } \\
\text { moderating role } \\
\text { played by socio } \\
\text { demographic } \\
\text { structure on the } \\
\text { relationship } \\
\text { between } \\
\text { socialization agents } \\
\text { and adolescent } \\
\text { consumer } \\
\text { vulnerability. }\end{array}$ \\
\hline
\end{tabular}




\begin{tabular}{|c|c|c|c|}
\hline $\begin{array}{l}\text { 4. Exposure to } \\
\text { TV } \\
\text { advertising on } \\
\text { adolescent } \\
\text { consumer } \\
\text { vulnerability. } \\
\text { 5. Retailers' } \\
\text { influence on } \\
\text { Consumer } \\
\text { Vulnerability. }\end{array}$ & $\begin{array}{l}\text { Adolescents are vulnerable due } \\
\text { to; } \\
\text { 1.Internet addiction (Kenneday } \\
\text { et al, 2019; Karacic and } \\
\text { Oreskovic, 2017), } \\
\text { 2. E-marketers' information } \\
\text { collection practices (Karacic \& } \\
\text { Kriz 2017; Lapierre et al., } \\
\text { 2017; Elizabeth et al., 2014; } \\
\text { Crosnoe \& McNeely, 2008). } \\
\text { 3. Higher exposure to social } \\
\text { media such as posting selfies } \\
\text { and following blogger (Fox and } \\
\text { Hoy, 2019; Berg, 2018; } \\
\text { Somasiri and Chandralal, 2018). } \\
\text { 4. Gaming addiction (Kuss and } \\
\text { Griffiths, 2012, Josephine et al } \\
\text { 2006). } \\
\text { TV Advertising } \\
\text { 1. Junk food marketing appeals } \\
\text { (Harris et al, 2020; Elliot, 2017; } \\
\text { Lapierre et al, 2017; Beaudon, } \\
\text { 2014), } \\
\text { situation, making them } \\
\text { powerless in decision making. } \\
\text { 2. Over exposure to TV } \\
\text { advertising (Galdolage \& } \\
\text { Wijesundara, 2007; Lenka \& } \\
\text { Vandana, 2015, Pechmann etal., } \\
\text { 2005; Lapierre etal., 2017; } \\
\text { Rowthorn 2017), } \\
\text { 3. Deceptive product claims in } \\
\text { ads (McInnis \& de Mello, 2005; } \\
\text { Watson et al, 2011), } \\
\text { (1) }\end{array}$ & $\begin{array}{l}\text { demographic variables as } \\
\text { follows. } \\
\text { Age cohorts (Lapierre et al, } \\
\text { 2017; Lenka and } \\
\text { Vandana,2015; Ozdogan } \\
\text { and Atlantis,2010; Chan et } \\
\text { al, 2010). } \\
\text { Gender (McCoy et al 2017; } \\
\text { Ozdogan and Atlantis, } \\
\text { 2010), } \\
\text { Family status (Gilmour et } \\
\text { al, 2020; Fox and Hoy, } \\
\text { 2019; Shin et al, 2019; } \\
\text { Lenka and Vandana, 2015; } \\
\text { Lueg et al, 2006) in } \\
\text { upcoming researches. } \\
\text { 3. Additionally, existing } \\
\text { literature lacks Longitudinal } \\
\text { research exploring how } \\
\text { youth process marketing } \\
\text { messages across media } \\
\text { platforms and across ages. } \\
\text { (Lapierre and Rozendaal, } \\
\text { 2019; Lapierre et al 2017). }\end{array}$ & $\begin{array}{l}\text { In the meantime, } \\
\text { majority of studies } \\
\text { are cross sectional } \\
\text { giving less attention } \\
\text { to the impact of } \\
\text { socio-demographic } \\
\text { changes on the } \\
\text { basic relationship. } \\
\text { So, longitudinal } \\
\text { research exploring } \\
\text { how socio } \\
\text { demographic } \\
\text { structure alter the } \\
\text { basic relationship } \\
\text { should also be } \\
\text { studied in } \\
\text { upcoming } \\
\text { researches. }\end{array}$ \\
\hline
\end{tabular}

\section{DISCUSSION AND CONCLUSION}

The aim of this systematic literature review is to understand different areas and future prospects within the field of Adolescent Consumer Vulnerability. The results of this review contribute to a better understanding of Adolescent Consumer Vulnerability and show important gaps for future researches. Although, significant amounts of studies are available to identify the adolescent vulnerability, the field lacks studies explaining the specific vulnerability that adolescents undergone through socialization. Within this backdrop, this study attempted to fill the existing knowledge gaps based on a comprehensive Review Protocol covering the specific questions addressed by the study, aim and scope of the study, 
the search strategy for identification of relevant studies, and the criteria for inclusion and exclusion of studies in the review. In line with the research questions, empirical justifications provided to each identified research area as follows.

Peer pressure on Adolescent Consumer Vulnerability is the first research area identified within the review, due to contradictory viewpoints in current literature. Here, some authors argue peer group influence is important for adolescents while some others claim; adolescent consumers are in a vulnerable situation due to peer pressure. Thus, the factors favouring peer group influence are; peers play a significant role in upbringing consumerism in children, peer groups are a essential element of adolescent life, adolescents develop consumption skills in relation to peers and media. In contrast, adolescents' incapability to manage peer pressure, frequent communication with peers before making purchase decision, direct influence in risk behaviour, normative influence on materialism and compulsive buying, purchase products to maintain group identity are some of the vulnerabilities identified by the previous researches. Furthermore, existing researchers suggested that peer pressure on adolescents should be studied in other cultures, with different socio-cultural backgrounds.

The second research area identified owing to unclear points within the existing literature relating to parents influence on adolescents buying behaviour. Out of the reviewed articles, majority discusses the positive influence of parents on adolescents' behaviour such as; Protection of various risk behaviours throughout adolescence, Important and informative role, Shape how adolescents make decisions regarding products, brands, and stores, Assistance to manage money, comparison shop, and assess price-quality relationships. However, few studies disclosed that adolescent consumers are in a vulnerable situation because of autonomy and economic independence given by parents to make purchase decisions. Adding to that, existing authors discovered that owing to changing demographics and busy schedules of families, young children make independent purchasing decisions. As such, it emphasizes the importance of studying the role of family structure on adolescent vulnerability in upcoming researches.

The third research area highlighted the lack of empirical findings related to the impact of Mass media advertising on Adolescent Consumer Vulnerability. Majority of studies emphasized that adolescents' degree of vulnerability to commercial messages is dependent on exposure to TV. Accordingly, adolescents are vulnerable in situations where they; use heavily advertised products, tend to trust advertisers' motives and view ads as beneficial, believe commercial messages and act accordingly, lack the cognitive capacity to protect themselves, are vulnerable to deceptive product claims, heavily influence on parent's decision making with regards to product choices and consumption patterns etc. Additionally, it uncovers that most of the existing research studies are widely explored in the USA, while very limited investigation in other cultures with different socio-demographic backgrounds. 
Adolescent Consumer Vulnerability in Online context is the fourth socialization agent identified within this review, due to its current importance within the present world. As such, the empirical findings discover that adolescents are particularly vulnerable due to; e-marketers' information collection practices, promotional messages that are skilfully blended with entertainment online, consumption learning practices based on social and entertainment activities via digital equipment and media, unprecedented access to individual consumer data along with a variety of direct-response and brand marketing opportunities and uploading photos in social media marketing. Meantime, the extant studies suggested having more researches in other cultures with different demographic and social backgrounds.

Finally, Retailers influence on adolescent consumer vulnerability is the fourth agent of socialization recognized within this study. As per the evidence, the attraction between malls and Generation Y consumers has received little interest from marketing academics. Additionally, it emphasises the significance of studying the behavioural change of adolescents in different socio-cultural backgrounds, to get a better picture of the phenomena in other cultures.

\section{APPENDIX - PRIMARY STUDIES}

P01 - Barber, N.A. (2013). Investigating the Potential Influence of the Internet as a New Socialization Agent in Context with Other Traditional Socialization Agents. The Journal of Marketing Theory and Practice, 21(2), 179-193.

P02 - Batat, W. (2008). Exploring adolescent development skills through Internet usage: a study of French 1115 year olds. International Journal of Consumer Studies, 32, 374-381.

P03 - Batat, W. (2010), Understanding the Dimensions of Young Consumer Vulnerability in the Web 2.0 Society, Child and Teen Consumption CTC, Norrköping, Sweden. 250.

P04 - Batat, W. (2012). How Do Adolescents Define Consumer Vulnerability? Toward a Youth-Centric Approach, in NA - Advances in Consumer Research Volume 40, eds. Zeynep Gürhan-Canli, Cele Otnes, and Rui (Juliet) Zhu, Duluth, MN : Association for Consumer Research, 751-752.

P05 - Batat, W., \& Tanner, J.F. Jr. (2019). Unveiling (In)Vulnerability in an Adolescent's Consumption Subculture: A Framework to Understand Adolescents' Experienced (In) Vulnerability and Ethical Implications, Journal of Business Ethics.

P06-Beaudon, C.E. (2014), The Mass Media and Adolescent Socialization: A Prospective Study in the Context of Unhealthy Food Advertising, Journalism \& Mass Communication Quarterly 2014, 91(3) 544-561.

P07-Berg, L. (2018). Young consumers in the digital era: The Selfie effect, International Journal of Consumer Studies. 42, 379-388.

P08-Chan, C., Prendergast, G., Grønhøj, A., Larsen, T.B. (2010), The Role Of Socializing Agents In Communicating Healthy Eating To Adolescents: A Cross Cultural Study, Journal of International Consumer Marketing, DOI: 10.1080/08961530.2011.524578.

P09-Crosnoe, R., \& McNeely, C. (2008). Peer Relations, Adolescent Behavior, and Public Health Research and Practice. Family and Community Health, 31(1), 71-80.

P10-Dotson, M.J., and Hyatt, E.M. (2005). Major influence factors in children's consumer socialization, Journal of Consumer Marketing, 22(1), 35-42. 
P11- Elliott, C. (2017), Knowledge needs and the 'savvy' child: teenager perspectives on banning food marketing to children, Critical Public Health, 27, (4), 430-442.

P12- Fortin, B., and Yazbeck, M., (2015): Peer Effects, Fast Food Consumption and Adolescent Weight Gain, IZA Discussion Papers, No. 9087, Institute for the Study of Labor (IZA), Bonn

P13 - Fox, A. K. \& Hoy, M.G. (2019). Smart Devices, Smart Decisions? Implications of Parents' Sharenting for Children's Online Privacy: An Investigation of Mothers, Journal of Public Policy \& Marketing, 38(4), 414432.

P14 - Gilmour, A., Gill, S., and Loudon, G. (2020). Young adolescents' experiences and views on eating and food, YOUNG CONSUMERS.

P15 - Grier, S., \& Davis, B. (2013). Are All Proximity Effects Created Equal? Fast Food Near Schools and Body Weight Among Diverse Adolescents. Journal of Public Policy \& Marketing, 32(1), 116128. doi:10.1509/jppm.11.158

P16 - Harris, J. L. \& Yokum, S., \& Milici, F.F. (2020). Hooked on Junk: Emerging Evidence on How Food Marketing Affects Adolescents' Diets and Long-Term Health, Food Addiction, A Meule Section Editor.

P17 - Hill, W.W., Beatty, S.E., Walsh, G. (2013). A segmentation of adolescent online users and shoppers, Journal of Services Marketing, 27(5), 347-360.

P18 - Josephine, P., Drennan, J., Mort, G.S., (2006). M-technology, Consumption and Gambling: A Conceptualisation of Consumer Vulnerability in an M-gambling Marketplace. In Layton, M., Layton, R., \& Wooliscroft, B. (Eds.) Macromarketing Seminar Proceedings: Macromarketing the Future of Marketing?, Marketing Department, University of Otago, New Zealand, Queenstown, 173-188.

P19- Karacic, S., \& Oreskovic, S. (2017). Internet addiction and Mental Health Status of Adolescents in Croatia and Germany. Psychiatria Danubina, 29(3), 313-321.

P20- Kennedy, A.M., Jones, K. \& Williams, J. (2019). Children as Vulnerable Consumers in Online Environments, The Journal of Consumer Affairs.

P21 - Kuss, D.J. \& Griffiths, M.D. (2012). Online gaming addiction in children and adolescents: A review of empirical research, Journal of Behavioural Addictions 1(1), 1-20.

P22 - Lapierre, M. A. \& Rozendaal, E. (2019). A Cross-National Study Examining the Role of Executive Function and Emotion Regulation in the Relationship between Children's Television Exposure and Consumer Behavior, Journal of Youth and Adolescence.

P23 - Lapierre, M.A., Milici, F.F., Rozendaal, E., McAlister, A. R., \& Castonguay, J. (2017). The Effect of Advertising on Children and Adolescents, Pediatrics, 140 (2), DOI: https://doi.org/10.1542/peds.2016-1758V

P24 - Lenka \& Vandana (2015). Direct and Indirect Influence of Interpersonal and Environmental Agents on Materialism in Children, National Academy of Psychology.

P25 - Lueg, J., Ponder, N., Beatty, S., \& Capella, M. (2006). Teenagers' use of alternative shopping channels: A Consumer Socialization Perspective, Journal of Retailing, 82 (2), 137-153.

P26- Mason, M. J., Tanner, J. F., Piacentini, M., Freeman, D., Anastasia, T., Batat, W., et al. (2013). Advancing a participatory approach for youth risk behavior: Foundations, distinctions, and research. Journal of Business Research, 66, 1235-1241.

P27- Mccoy, S.S., Dimler, L.M., Samuels, D.V., Natsuaki, M.N. (2017), Adolescent Susceptibility to Deviant Peer Pressure: Does Gender Matter? Adolescent Res Rev, 4, 59-71. 
P28- Miller, H. V. (2009). If your friends jumped off a bridge, would you do it too? Delinquent peers and susceptibility to peer influence. Justice Quarterly, 27(4), 473-491. doi:10.1080/07418820903218974.

P29- Montgomery, K.C. \& Chester, J.M.S.W, (2009). Interactive Food and Beverage Marketing: Targeting Adolescents in the Digital Age, Journal of Adolescent Health, 45.

P30- Nairn, A. \& Berthon, P. (2005). Affecting Adolescence: Scrutinizing the Link Between Advertising and Segmentation, Business \& Society, 3, 318-345.

P31- Niankara, I., Al adwan, M.N., and Niankara, A. (2020). The Role of Digital Media in Shaping Youth Planetary Health Interests in the Global Economy, Journal of Open Innovation, 6(49).

P32- Ozdogan, F.B., \& Altintas, M.H. (2010). Parent-adolescent interaction and the family's effect on adolescent TV skepticism: an empirical analysis with Turkish consumers. Young Consumers, 11(1), 24-35.

P33- Pechmann, C., Levine, L., Loughlin, S., \& Leslie, F. (2005). Impulsive and Self-Conscious: Adolescents' Vulnerability to Advertising and Promotion, Journal of Public Policy \& Marketing, 24 (2).

P34- Roberts, J.A., Manolis, C., \& Tanner, J. F. (Jeff) Jr. (2008). Interpersonal influence and adolescent materialism and compulsive buying, Social Influence, 3(2), 114-131.

P35- Rydell, S.A., Harnack, L.J., Oakes, J. M., Story, M., Jeffery, R.W., French, S. A. (2008). Why Eat at FastFood Restaurants: Reported Reasons among Frequent Consumer, Journal Of The American Dietetic Association, 108, 2066-2070.

P36- Shin, W., Lwin, M. O., Yee, A. Z. H. \& Kalya M. Kee (2019): The role of socialization agents in adolescents' responses to app-based mobile advertising, International Journal of Advertising, DOI: 10.1080/02650487.2019.1648138

P37- Spotswood, F., \& Nairn, A. (2016). Children as vulnerable consumers: A first conceptualization. Journal of Marketing Management, 32, 211-229.

P38- Thyne, M., Robertson, K., Watkins, L., \& Casey, O. (2019). Retailers targeting children with set collection promotions: the child's perspective. International Journal of Retail \& Distribution Management. doi:10.1108/ijrdm-08-2017-0180

P39- Tom, G., \& Matos, M.G. De (2012). How Can Peer Group Influence the Behavior of Adolescents: Explanatory Model? Global Journal of Health Science, 4(2), 26-35.

P40- Youn, S. (2009), Determinants of Online Privacy Concern and Its Influence on Privacy Protection Behaviours among Young Adolescents. The Journal of Consumer Affairs, 43(3).

\section{REFERENCE}

Abbas, F., Junaid, M., Ahsan, A., \& Zafar, M.Z. (2013). Impact of Socialization Agents on Teenagers, A case from Pakistan. SS International Journal. 3(5), 46-54.

Aronson, E., Timothy, D. W., \& Robin, M. Akert (2009), Social Psychology, 7th ed., Upper Saddle River, NJ: Prentice Hall.

Baker, S.M., Gentry, J.W., and Rittenburg, T.L. (2005). Building understanding of the domain of consumer vulnerability, Journal of Micromarketing, 25 (2), 128-139.

Batat, W. (2008). Exploring adolescent development skills through Internet usage: a study of French 11-15 year olds. International Journal of Consumer Studies, 32, 374-381.

Batat, W. (2010). Understanding the Dimensions of Young Consumer Vulnerability in the Web 2.0 Society, Child and Teen Consumption CTC, Norrköping, Sweden. 250. 
Batat, W. (2012). How Do Adolescents Define Consumer Vulnerability? Toward a Youth-Centric Approach, in NA Advances in Consumer Research Volume 40, eds. Zeynep Gürhan-Canli, Cele Otnes, and Rui (Juliet) Zhu, Duluth, MN : Association for Consumer Research, 751-752.

Batat, W., \& Tanner, J.F. Jr. (2019). Unveiling (In) Vulnerability in an Adolescent's Consumption Subculture: A Framework to Understand Adolescents' Experienced (In) Vulnerability and Ethical Implications, Journal of Business Ethics.

Barber, N.A. (2013). Investigating the Potential Influence of the Internet as a New Socialization Agent in Context with Other Traditional Socialization Agents. The Journal of Marketing Theory and Practice, 21(2), 179-193.

Beaudon, C.E., (2014), The Mass Media and Adolescent Socialization: A Prospective Study in the Context of Unhealthy Food Advertising, Journalism \& Mass Communication Quarterly, 91(3) 544-561.

Bearden, W.O., Netemeyer, R.G., \& Teel, J.E. (1989). Measurement of consumer susceptibility to interpersonal influence. Journal of Consumer Research, 15(4), 473-481.

Berg, L. (2015). Consumer Vulnerability: Are older people more vulnerable as consumers than others?, International Journal of Consumer Studies.

Bowman, S.A., Gort Maker, S.L., Ebbeling, C.B., Perara, M. A., Ludwig, D. S. (2004). Effects of fast food consumption on energy intake and diet quality among children in a national house hold survey:www.uptodate.co/ contents/fast food_for_children_and_adolescents/abtract/11 -13. Pediatrics.113 (1pt1):112

Broderick, A.J., Demangeot, C., Adkins, N.R., Ferguson, N.S., \& Henderson, G.R. (2011). Consumer Empowerment in Multicultural Marketplaces: Navigating Multicultural Identities to Reduce Consumer Vulnerability, Marketing Faculty Publications, 50 .

Byrnes, J. P., Miller, D. C., \& Schafer, W. D. (1999). Gender differences in risk-taking: A meta-analysis. Psychological Bulletin, 125(3), 367-383. doi: 10.1037/0033-2909.125.3.367.

Canhotoa, A.I. \& Dibbb, S. (2016). Journal of Marketing Management, 32, (3-4), 335-356.

Chan, C., Prendergast, G., Grønhøj, A., Larsen, T.B. (2010). The Role Of Socializing Agents In Communicating Healthy Eating To Adolescents: A Cross Cultural Study, Journal of International Consumer Marketing, DOI: 10.1080/08961530.2011.524578.

Chaudhary, M., (2016). Involvement of Children in the Family Buying: A Review, Journal of Pacific Business Review, 8(11).

Clark, R.A., \& Goldsmith, R.E. (2005). Market mavens: Psychological influences. Psychology and Marketing, 22, 289-312.

Coleman, J. C. \& Hendry, L. B. (1999). The nature of adolescence (3rd Edition). London: Routledge.

Commuri, S., and Ekici, A. (2008). An Enlargement of the Notion of Consumer Vulnerability, Journal of Macromarketing, 28, 183.

Cotterell, J. (1996). Social networks and social influences in adolescence. New York: Routledge.

Craig, A. M. \& Turley, L.W. (2004). Malls and consumption motivation: an exploratory examination of older Generation Y consumers. International Journal of Retail \& Distribution Management. 32(10), 464 - 475.

Crosnoe, R. \& McNeely, C. (2008). Peer Relations, Adolescent Behavior, and Public Health Research and Practice. Family and Community Health, 31(1), 71-80.

Crowell, A. (2014). Bachelor's thesis submitted to Honors College at the College of Charleston.

Davies, H. T. O., \& Crombie L. K. (1998). Getting to Grips with Systematic Reviews and Meta-Analyses, Hospital Medicine, 59 (12), 955-958. 
Dotson, M.J. and Hyatt, E.M. (2005). Major influence factors in children's consumer socialization, Journal of Consumer Marketing 22(1), 35-42.

Durkin, K. (1997). Developmental Social Psychology: From Infancy to Old Age. Malden, MA Blackwell.

Edens, K.M., \& McCormick, C.B. (2000). How Do Adolescents Process Advertisements? The Influence of Ad Characteristics, Processing Objective, and Gender, Contemporary Educational Psychology, 25, 450-463.

Elliott, C. (2017). Knowledge needs and the 'savvy' child: teenager perspectives on banning food marketing to children, Critical Public Health, 27(4), 430-442.

Faber, R. J., \& O'Guinn, T. C. (1988). Expanding the view of consumer socialization: A non-utilitarian mass-mediated perspective. Research in Consumer Behaviour, 3, 49-77.

FCA. (2014). Consumer credit and consumers in vulnerable circumstances. London: Financial Conduct Authority.

Fono, D., \& Raynes-Goldie, K. (2006). Hyperfriends and Beyond: Friendship and Social Norms on LiveJournal. M. Consalvo \& C. Haythornthwaite (Eds.), Internet Research Annual, 4.

Fortin, B., and Yazbeck, M., (2015): Peer Effects, Fast Food Consumption and Adolescent Weight Gain, IZA Discussion Papers, No. 9087, Institute for the Study of Labor (IZA), Bonn

Fox, A. K. \& Hoy, M.G. (2019). Smart Devices, Smart Decisions? Implications of Parents' Sharenting for Children's Online Privacy: An Investigation of Mothers, Journal of Public Policy \& Marketing, 38(4), 414-432.

Gilmour, A., Gill, S., and Loudon, G. (2020). Young adolescents' experiences and views on eating and food, YOUNG CONSUMERS.

Grier, S., \& Davis, B. (2013). Are All Proximity Effects Created Equal? Fast Food Near Schools and Body Weight Among Diverse Adolescents. Journal of Public Policy \& Marketing, 32(1), 116-128. doi:10.1509/jppm.11.158.

Hall, Carol. (1987). Teen Power: Youth's Middle Tier Comes of Age. Marketing and Media Decisions, 56-62.

Hanson, M.D, \& Chen E. (2007). Socioeconomic Status and Health Behaviours in Adolescence: A Review of the Literature. J Behav Med, 30(3):263-285. doi: 10.1007/s10865-007-9098-3.

Hill, W.W., Beatty, S.E., Walsh, G. (2013). A segmentation of adolescent online users and shoppers, Journal of Services Marketing, 27(5), 347-360.

Jain, N., \& Sharma, N. (2016). Measuring the Effect Of Pester Power on Family Buying Decision in FMCG Products Using Factor Analysis. Imperial Journal of Interdisciplinary Research, 2(4).

Jayasundara, S.K., Siriwardhana, S. \& Jayawickrama, W.D.C. (2020), Enabling vulnerable populations: insights from the experiences of functionality illiterate consumers, Journal of Social Marketing.

John, D.R. (1999), Consumer Socialization of Children: A Retrospective Look at Twenty-Five Years of Research, Journal of Consumer Research, 26.

Josephine, P., Drennan, J., Mort, G.S., (2006). M-technology, Consumption and Gambling: A Conceptualisation of Consumer Vulnerability in an M-gambling Marketplace. In Layton, M, Layton, R, \& Wooliscroft, B (Eds.) Macromarketing Seminar Proceedings: Macromarketing the Future of Marketing?, Marketing Department, University of Otago, New Zealand, Queenstown, 173-188.

Judi, H. M., Ashaari, N.S., Zin, N.A.M., Yusof, Z.M. (2013). Framework of ICT Impact on Adolescent, The 4th International Conference on Electrical Engineering and Informatics, Procedia Technology, 11, 1034 - 1040. 
Kahre, A., Praveen, C., \& Mishra., A. (2012). Influence of normative and informative values on fashion clothing involvement of Indian women, Journal of Customer Behaviour, 11(1), 9-32.

Karacic, S., \& Kriz, S. (2017). Internet addiction and Mental Health Status of Adolescents in Croatia and Germany. Psychiatria Danubina, 29(3), 313-321.

Kennedy, A.M., Jones, K. \& Williams, J. (2019). Children as Vulnerable Consumers in Online Environments, The Journal of Consumer Affairs.

Khan, G., \& Naila, K., (2008). Gender Differences in Susceptibility to Normative Social Influence on the Purchase Decisions of Designer Label Apparel, International Business \& Economics Research Journal, 7 (8), 11-57.

Khan,T., Powell, L.M. and Wada, R. (2012). Fast Food Consumption and Food Prices: Evidence from Panel Data on 5th and 8th Grade Children, Journal of Obesity, Special issue Behavioural Determinants of Obesity: Research Findings and Policy Implications.

Kitchenham, B. and Charters, S. (2007). Guidelines for performing systematic literature reviews in software engineering. Engineering, 2(EBSE 2007-001).

Kuss, D.J. and Griffiths, M.D. (2012). Online gaming addiction in children and adolescents: A review of empirical research, Journal of Behavioural Addictions 1(1), 1-20.

Lacoba, M. R., Garcia, P. Saus, A.E., Sotos, E.F (2020). Social determinants of food group consumption based on Mediterranean diet pyramid: A cross-sectional study of university students.

Lapierre, M.A., Milici, F.F., Rozendaal, E., McAlister, A. R., \& Castonguay, J. (2017). The Effect of Advertising on Children and Adolescents, Pediatrics, 140 (2), DOI: https://doi.org/10.1542/peds.2016-1758V

Lenka \& Vandana (2015), Direct and Indirect Influence of Interpersonal and Environmental Agents on Materialism in Children, National Academy of Psychology.

Lenka \& Vandana (2015), A Review on Impact of Socialization Agents in Breeding Consumerism among Children, Global Business Review, 16(5), 867-878.

Li, L., Sun,N.'Zhang, L., Xu, G., Liu, J., Hu, J., Zhang, Z., Lou, J., Deng, H., Shen, Z., and Han' H. (2020), Fast food consumption among young adolescents aged 12-15 years in 54 low- and middle-income countries, Global Health Action, 13(1).

Lueg, J., Ponder, N., Beatty, S., \& Capella, M. (2006), Teenagers' use of alternative shopping channels: A Consumer Socialization Perspective, Journal of Retailing, 82 (2), 137-153.

Luo, X. (2005). How does shopping with others influence impulsive purchasing? Journal of Consumer Psychology, $15,288-294$.

Mangleburg, T., Grewal, D., \& Bristol, T., (1997). Socialization, Gender, and Adolescent's Self-Reports of Their Generalized Use of Product Labels, The Journal of Consumer Affairs, 31 (2), 255-279.

Mascarenhas, O.A.J., \& Higby, M. A. (1993). Peer, Parent, and Media Influences in Teen Apparel Shopping, Journal of the Academy of Marketing Science, 21 (1), 53-58.

Mason, M. J., Tanner, J. F., Piacentini, M., Freeman, D., Anastasia, T., Batat, W., et al. (2013). Advancing a participatory approach for youth risk behavior: Foundations, distinctions, and research. Journal of Business Research, 66, 1235-1241.

Mccoy, S.S., Dimler, L.M., Samuels, D.V., Natsuaki, M.N. (2019), Adolescent Susceptibility to Deviant Peer Pressure: Does Gender Matter? Adolescent Res Rev, 4, 59-71. 
Mears, D. P., Ploeger, M., \& Warr, M. (1998). Explaining the gender gap in delinquency: Peer influence and moral evaluations of behaviour. Journal of Crime and Delinquency, 35(3), 251-266. doi: $10.1177 / 0022427898035003001$.

Melnikas, B. \& Smaliukiene, R. (2007). Consumer Vulnerability in Pharmaceutical Market: Case of Baltic Countries, Journal of Business Economics and Management, 8(1), 51-62.

Miller, H. V. (2009). If your friends jumped off a bridge, would you do it too? Delinquent peers and susceptibility to peer influence. Justice Quarterly, 27(4), 473-491. doi:10.1080/07418820903218974.

Montgomery, K.C. \& Chester, J.M.S.W, (2009). Interactive Food and Beverage Marketing: Targeting Adolescents in the Digital Age, Journal of Adolescent Health, 45.

Moschis, G.P. (2011), Religiosity and consumer behavior of older adults: a study of subcultural influences in Malaysia. Journal of Consumer Behaviour, 10(1), 8-17.

Nairn, A. \& Berthon, P. (2005). Affecting Adolescence: Scrutinizing the Link Between Advertising and Segmentation, Business \& Society, 3, 318-345.

Niankara, I., Al adwan, M.N., and Niankara, A. (2020), The Role of Digital Media in Shaping Youth Planetary Health Interests in the Global Economy, Journal of Open Innovation, 6(49).

Nishadi, T. (June 17, 2020). Financial Consumer Protection is not a Destination, it's a Journey, Daily FT Sri Lanka.

Nora, A., ALFaris, Jozaa Z., Al-Tamimi, Moneera, O., Al-Jobair \& Naseem, M. AlShwaiyat (2015). Trends of fast food consumption among adolescent and young adult Saudi girls living in Riyadh, Food \& Nutrition Research, 59(1), 26488, DOI: 10.3402/fnr.v59.26488

Osorio, S. (1995). Teen spending soars to \$96 million in 1994. Tucson Citizen.

Ozdogan, F.B., \& Altintas, M.H. (2010). Parent-adolescent interaction and the family's effect on adolescent TV skepticism: an empirical analysis with Turkish consumers. Young Consumers, 11(1), 24-35.

Paul, H.R., \& Sharma, E. (2020). Consumer Vulnerability, Journal of Consumer Psychology, 30(3), 551-570.

Paniagua, S.M. P., Milena, A. P., de Torres, L.A. P., García, J.A. F., Alconada, J. M. (2014). Food consumption patterns among adolescents, Anales Sis San Navarra, 37(1), 47-58.

Pechmann, C., Levine, L., Loughlin, S., \& Leslie, F. (2005). Impulsive and Self-Conscious: Adolescents' Vulnerability to Advertising and Promotion, Journal of Public Policy \& Marketing, 24 (2).

Pechmann, C., Moore, E. S., Andreasen, A. R., Connell, P. M., Freeman, D., Gardner, M. P., Heisley, D., Lefebvre, R. C., Pirouz, D. M., \& Soster, R. L. (2011). Navigating the central tensions in research on consumers who are at risk: challenges and opportunities, Journal of Public Policy and Marketing. 30(1), 23-30.

Ranjith, N., Wilkinson, A.V., Lytle, L.M., Evans, A.E., Saxton, D., Hoelscher, D.M. (2015). Socio-economic inequalities in Children's diet: the role of home food environment, International Journal of Behavioural Nutrition and Physical Activity, 12(1).

Ringold, D.J. (2005), Vulnerability in the Marketplace: Concepts, Caveats, and Possible Solutions, Journal of Macromarketing, 25(2), 202-214.

Roberts, J.A., Manolis, C., \& Tanner, J. F. (Jeff) Jr. (2008), Interpersonal influence and adolescent materialism and compulsive buying, Social Influence, 3(2), 114-131.

Rydell, S.A., Harnack, L.J., Oakes, J. M., Story, M., Jeffery, R.W., French, S. A. (2008). Why Eat at Fast-Food Restaurants: Reported Reasons among Frequent Consumer, Journal Of The American Dietetic Association, 108, 2066-2070. 
Shim, S. (1996). Adolescent Consumer Decision-Making Styles: The Consumer Socialization Perspective. Psychology \& Marketing, 13(6), 547-569.

Shim, S., \& Koh, A. (1997). Profiling Adolescent Consumer Decision-Making Styles: Effects of Socialization Agents and Social-Structural Variables. Clothing and Textiles Research Journal, 15(1), 50-59. doi:10.1177/0887302x9701500106.

Shin, W., Lwin, M. O., Yee, A. Z. H. \& Kalya M. Kee (2019): The role of socialization agents in adolescents' responses to app-based mobile advertising, International Journal of Advertising, DOI: 10.1080/02650487.2019.1648138

Silvera, D.H., Meyer, T., Laufer, D. (2012). Age related reactions to a product harm crisis, Journal of Consumer Marketing, 29(4), 302-309.

Singh, Nitish., Ik-Whan, K., and Arun P. (2003). Cross-Cultural Consumer Socialization: An Exploratory Study of Socialization Influences Across Three Ethnic Groups. Psychology \& Marketing, 20 (10), 867-881.

Skaradal, M., Western, I.M., Ask., Øverby, N.C. (2014). Socioeconomic differences in selected dietary habits among Norwegian 13-14-year-olds: a cross-sectional study. Food and Nutrition Research, 58(1).

Somasiri, S., \& Chandralal, L. (2018), Theorizing Deviant Consumer Socialization: With Special Reference to Compulsive Buying Behavior. A Review of Literature, European Academic Research. 6(1).

Spotswood, F., \& Nairn, A. (2016). Children as vulnerable consumers: A first conceptualization. Journal of Marketing Management, 32, 211-229.

Steinberg, Laurence D. (2002), Adolescence, 6th ed. Boston: McGraw-Hill.

Stewart, R., \& Yap, S.F. (2020). Low literacy, policy and consumer vulnerability: Are we really doing enough? International Journal of Consumer Studies, 00,1-10.

Svastisalee, C.M. Holstein, B.E., Due, P. (2012). Fruit and Vegetable intake in Adolescents: Association with Socioeconomic Status and Exposure to Supermarkets and Fast Food Outlets, Journal of Nutrition and Metabolism.

Svensson, R. (2003). Gender differences in adolescent drug use: The impact of parental monitoring and peer deviance. Youth and Society, 34(3), 300-329. doi:10.1177/0044118X02250095.

Taylor, C. R., S. Landreth, and H.-K. Bang. (2005). Asian Americans in magazine advertising: Portrayals of the model minority. Journal of Macromarketing, 25 (2), 163-174.

Thyne, M., Robertson, K., Watkins, L., \& Casey, O. (2019). Retailers targeting children with set collection promotions: the child's perspective. International Journal of Retail \& Distribution Management. doi:10.1108/ijrdm-08-2017-0180

Tom, G., \& Matos, M.G. De (2012). How Can Peer Group Influence the Behaviour of Adolescents: Explanatory Model? Global Journal of Health Science, 4(2), 26-35.

Tranfield, D., Denyer, D., \& Smart, P. (2003). Towards a Methodology for Developing Evidence-Informed Management Knowledge by Means of Systematic Review, British Journal of Management, 14. 207-222.

Tufte, B. (2003). Children, media and consumption. Advertising and Marketing to Children, 5, 69-75.

Ubayachandra, E.G., \& Eldeniya, N.C. (2017). Socialization of Consumers: A Phenomenological Review, Sri Lanka Journal of Marketing, 3(2), 1-15.

Wills, W.J., Backett-Milburn, K., Lawton, J. \& Roberts, E.M. (2009). Consuming Fast Food: The perceptions and practices of middle-class young teenagers in Children, Food and Identity in Everyday Life. James, A., Kjørholt , A., Tingstad, V. (eds). London, Palgrave Macmillan.

Youn, S. (2009), Determinants of Online Privacy Concern and Its Influence on Privacy Protection Behaviours among Young Adolescents. The Journal of Consumer Affairs, 43(3). 